\title{
Novel Pathway of Heat Shock- Induced Resistance in Tomato
}

\author{
Nur Akbar Arofatullah ${ }^{1}$, Tatsuo Sato ${ }^{2, *}$, Sayuri Tanabata $^{3}$ \\ ${ }^{1}$ United Graduate School of Agriculture, Tokyo University of Agriculture and Technology, 3-8-1 Saiwaicho, \\ Fuchu, Tokyo, Japan \\ ${ }^{2,3}$ Center for International Field Agriculture Research \& Education, College of Agriculture, Ibaraki University, \\ Ami 4668-1, Ami, Inashiki, Ibaraki, Japan Tatsuo \\ ${ }^{2}$ sugar@mx.ibaraki.ac.jp* \\ * corresponding author
}

Submission date: 10 Juli 2018, Receipt date: 10 Oktober 2019, Publication date: 1 Juli 2020

\begin{abstract}
High-temperature treatment induces disease resistance in various plants (heat shockinduced resistance; HSIR). The role of heat shock transcriptional factors (Hsfs) was investigated in this paper. Heat shock treatment induced disease resistance and upregulate gene expression of pathogenesis related protein; PRIa2 at 12 and $24 \mathrm{~h}$ after treatment. PRla2 has putative Hsfs binding site in the upstream area. On the other hand, a heat shock transcription factor HsfA2 up-regulated at 6 h after treatment, which was 6 h earlier than salicylic acid accumulation. This time lag suggested the direct contribution of HSfs, additionally to salicylic acid pathway in the regulation of HSIR in tomato.
\end{abstract}

Keywords: Acquired resistance, Heat shock transcription factor, Plant immunity, Plantpathogen interaction

\section{INTRODUCTION}

Plants activated disease resistance under heat stress condition has been known as heat shock-induced resistance (HSIR) (Widiastuti et al., 2011). Heat shock (HS) accumulated salicylic acid (SA), the primary signaling molecule in systemic acquired resistance (SAR). In the study, the researchers tried to elucidate the possibility that HSIR were regulated by heat shock transcription factors (Hsfs) and heat shock calculated as follows: disease index $=[\Sigma(\mathrm{n} \times \mathrm{v}) / \mathrm{N} \times \mathrm{Z}] \times 100 \%$, where $\mathrm{n}$ is the lesion score class, $\mathrm{v}$ is the number of samples in the score class, $\mathrm{N}$ is the highest score value, and $\mathrm{Z}$ is the total number of samples. Whole seedlings or only the 1 st leaf of tomato seedlings at the two-leaf stage were dipped upside down into the water at $45^{\circ} \mathrm{C}$, for 2 min (HST). Non-treated (NT) plants were used as negative controls. For time-course sampling, RNA was extracted from the 1 st leaf at different time intervals $(3,6,12,24$, 48 , or $72 \mathrm{~h}$ after HST) and used for gene expression analysis by qPCR using genespecific primers of PR1a2 and HsfA2. Total salicylic acid content was measured by LCMS/MS. element (HSE). HsfA2 is a heat stress-inducible protein themselves in tomato (Treuter et al., 1993). When the organism is exposed to HS, HsfA2 attach to HsfA1 and form a super-activator complex that regulates gene expression by binding to HSE located in the upstream regions of genes essential for survival under stress conditions (Hahn et al., 2011). Certain stress-related genes have HSEs and to be regulated by Hsfs (Storozhenko et al., 1998). Also, the transcription of pathogenesis-related (PR) genes 
could be regulated by Hsfs (Kumar et al., 2009). The objective of the study is to assess the role of Hsfs in the regulation of HSIR.

\section{RESEARCH METHODS}

Two-leaf stages of tomato 'Natsunokoma' and Pseudomonas syringae (Pst) strain MAFF902666 were used as biological materials. Pst was inoculated to tomato by dipping into bacterial suspension at $2 \times 10^{7} \mathrm{CFU}$. Lesion score was determined by lesion area at 3 days after inoculation as follows: 0 , healthy leaf; 1 , less than $10 \% ; 2,10 \%$ or more; $3,30 \%$ or more; and 4 , more than $40 \%$.

\section{RESULTS AND DISCUSSION}

The preventive value peaked at $12 \mathrm{~h}$ and decreased continuously until $48 \mathrm{~h}$ after HST (Fig. 1).

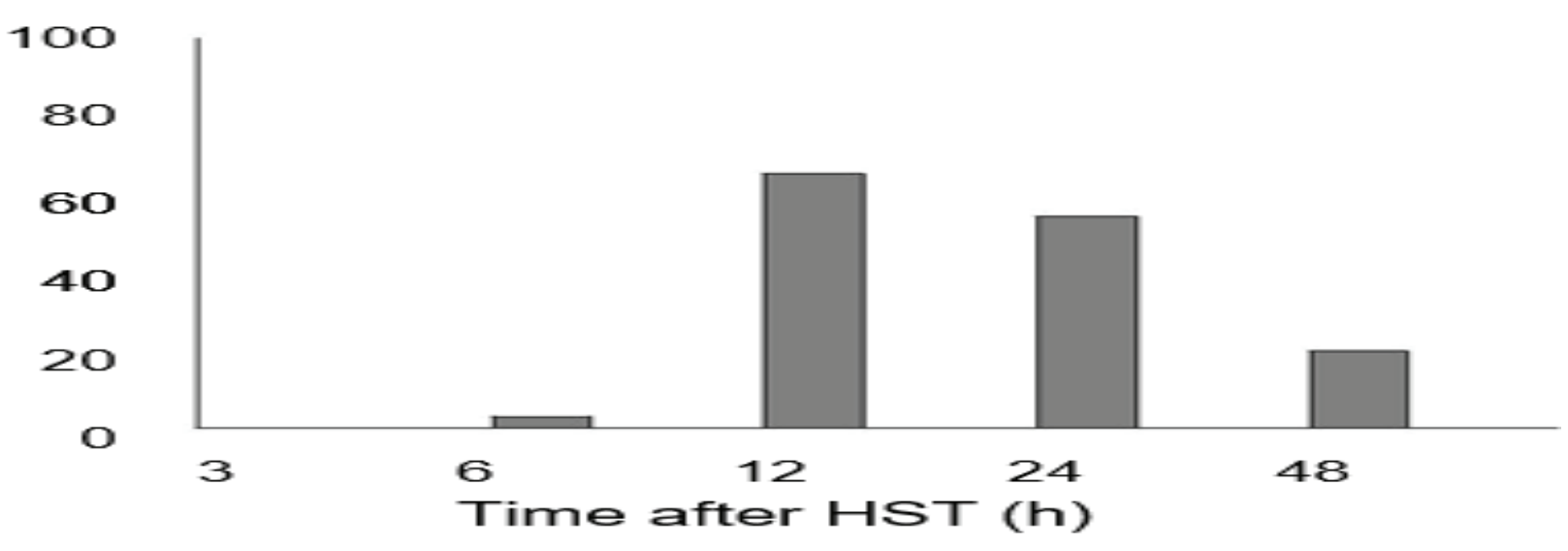

Fig 1. Induction of disease resistance against Pst. Pst was inoculated at 3, 6, 12, 24 and $48 \mathrm{~h}$ after $\operatorname{HST}\left(45^{\circ} \mathrm{C}, 2 \mathrm{mins}\right)$. Three plants were used for each replication.

The reduction of Pst lesion suggested that tomato defense response against Pst was induced by HST. PRla2 was upregulated at $12 \mathrm{~h}$ and peaked at $24 \mathrm{~h}$ after HST (Fig. 2). On the contrary, HsAf2 was peaked at $6 \mathrm{~h}$ after HST (Fig. 3).

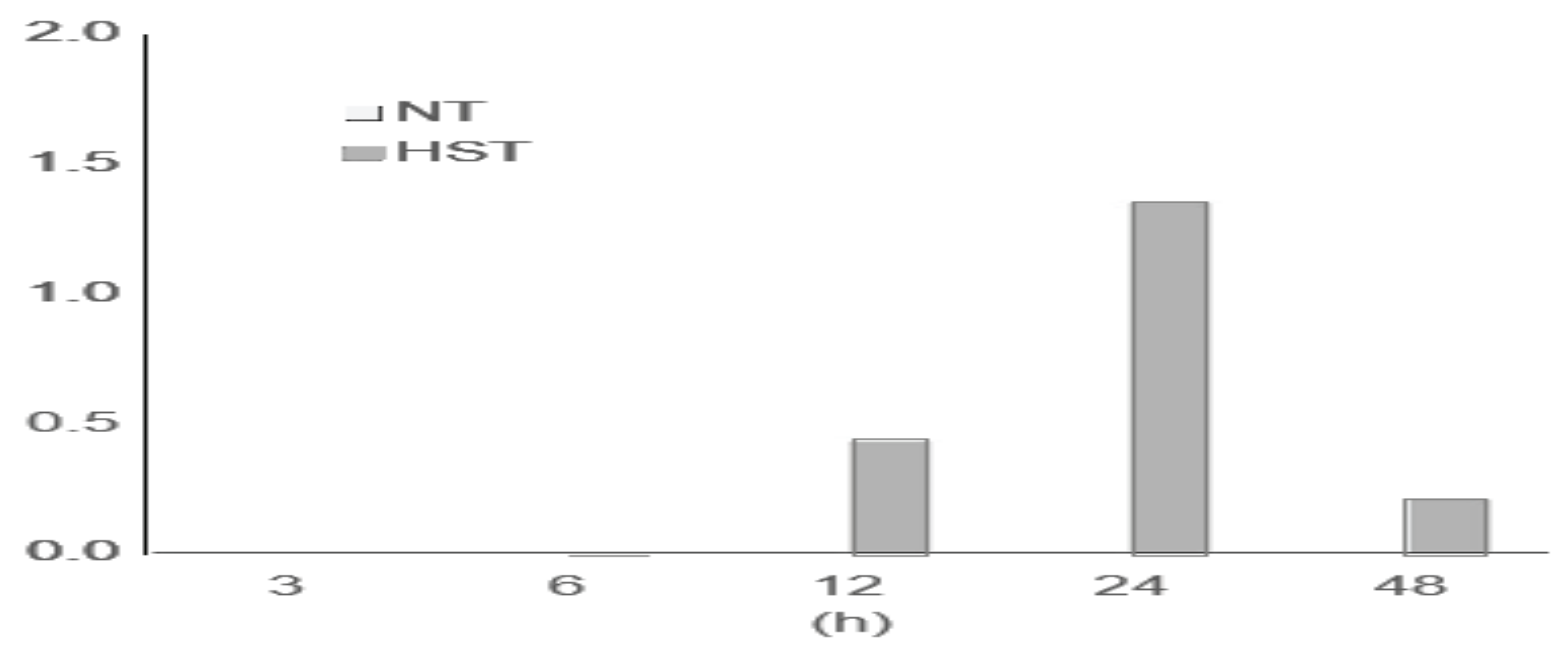

Fig 2. Changes in PR1a2 expression. $(n=4)$ 


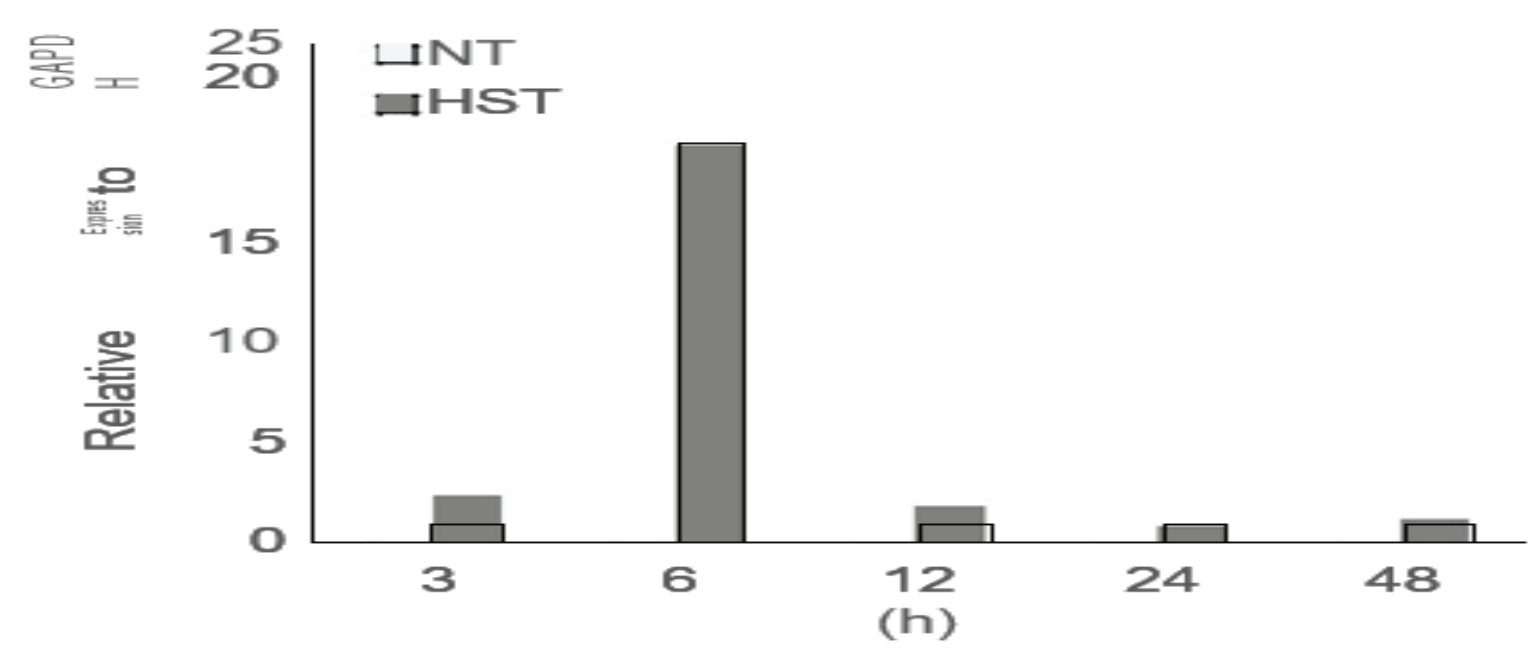

Fig 3. Changes in HsfA2 expression. $(n=4)$.

SA peaked at $12 \mathrm{~h}$ after HST and decreased. (Fig. 4). Transient expression of PRla2 corresponding with the appearance of induced resistance against Pst suggested that the expression of these genes was triggered on the pathway of HSIR. The expression pattern was different with $H s f A 2$. These results suggested possibilities that Hsfs was activated earlier than SA accumulation or PR gene expression after HST. This suggested that Hsfs can be the trigger molecules for inducing defense responses following HST, in addition to SAR. Four possible HSE motifs; 5'-nGAAn-3' or 5'nTTCn-3'were found on PRla2 at $-381,-1492,-1643$ and -1889 bp from start codon. As far as the authors investigated, all tested PR genes possessed these motifs (Data not shown). It is possible that the existence of HSE on the upstream area contributes to the HS induction of PR genes, although further experimentation is required to confirm the corresponding HSE on PR gene is recognized by Hsfs.

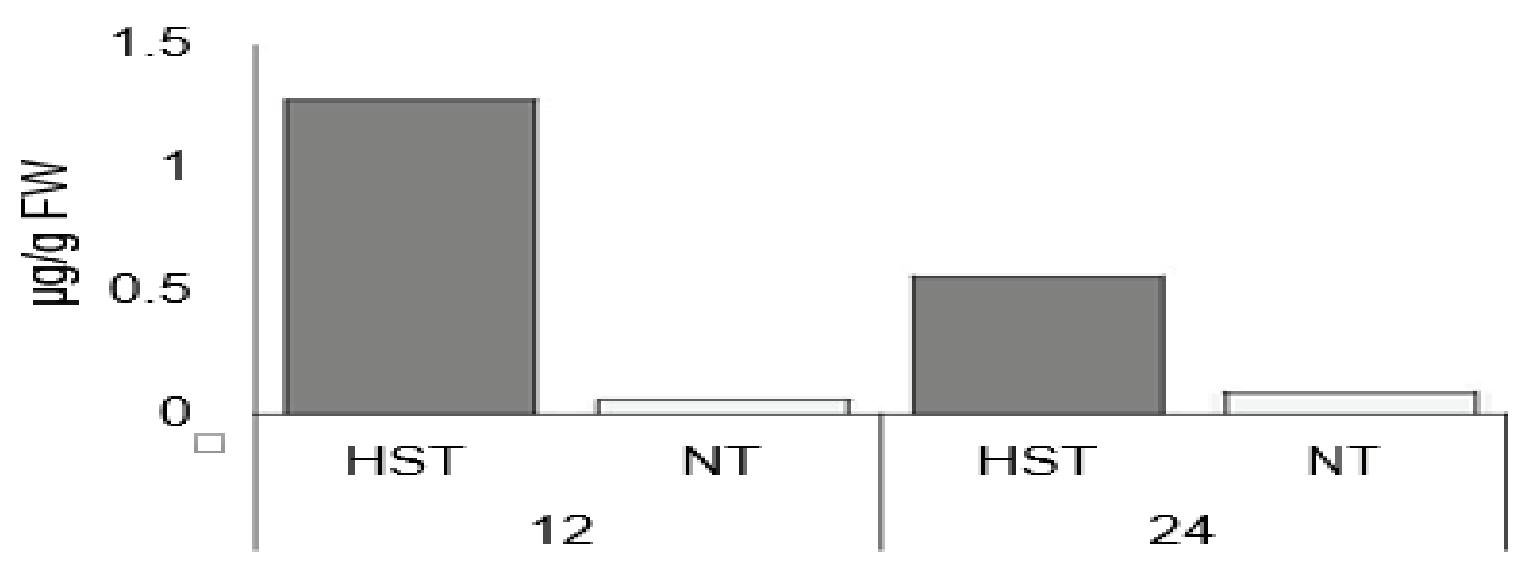

Fig 4. Accumulation of total SA after HST.

\section{CONCLUSION}

These results suggested that Hsfs was activated earlier than SA accumulation or PR gene expression after HST 


\section{REFERENCES}

Hahn, A.; Bublak, D.; Schleiff, E.; Scharf, K.D. Crosstalk between Hsp90 and Hsp70 chaperones and heat stress transcription factors in tomato. Plant Cell 2011, 23, 741-755.

Kumar, M.; Busch, W.; Birke, H.; Kemmerling, B.; Nürnberger, T.; Schöffl, F. Heat shock factors $\mathrm{HsfB} 1$ and $\mathrm{HsfB} 2 \mathrm{~b}$ are involved in the regulation of Pdf1.2 expression and pathogen resistance in Arabidopsis. Mol Plant 2009, 2, 152-165.

Storozhenko, S.; De Pauw, P.; Van Montagu, M.; Inzé, D.; Kushnir, S. The heat-shock element is a functional component of the Arabidopsis APX1 gene promoter. Plant Physiol 1998, 118, 1005- 1014.

Treuter, E.; Nover, L.; Ohme, K.; Scharf, K.D. Promoter specificity and deletion analysis of three heat stress transcription factors of tomato. Mol Gen Genet 1993, 240, 113-125.

Widiastuti, A.; Yoshino, M.; Saito, H.; Maejima, K.; Zhou, S.; Odani, H.; Hasegawa, M.; Nitta, Y.; Sato, T. Induction of disease resistance against Botrytis cinerea by heat shock treatment in melon (Cucumis melo L.). Physiol Mol Plant Pathol 2011, $75,157-162$. 